\title{
Anatomia da folha das espécies \\ conhecidas de pau-rosa. X - Citomorfologia das epidermes \\ superior e inferior de Aniba permollis (Nees) Mez (Lauraceae)
}

\author{
Italo de Vattimo (*)
}

\begin{abstract}
Resumo
Em continuação aos estudos desenvolvidos pelo Autor sobre a anatomia da folha das espécies conhecidas por "pau-rosa" ou "louro-rosa", este trabalho trata da citomorfologia das epidermes da folha de Aniba permollis (Nees)Mez (Lauraceae).
\end{abstract}

INTRODUÇÃo

O Autor continua o estudo citomorfológico da folha das espécies conhecidas de paurosa ou louro-rosa, de importância para a ciência por apresentarem óleos essenciais, tendo dedicado seus outros nove trabalhos às seguintes espécies de Aniba Aubl. (Kostermans, 1938): Aniba rosaeodora Ducke (conhecida nas Guianas Inglesa e Francesa como pau-rosa-fêmea e no Surinã como pau-rosaverdadeiro), Aniba duckei Kostermans, Aniba parviflora (Meissn.) Mez e Aniba terminalis Ducke.

\section{MATERIAL E MÉTODOS}

O estudo foi realizado na Seção de Geobotânica do Jardim Botânico do Rio de Janeiro, com folhas de material seco (desde que o objetivo dos trabalhos é a organização de uma chave para identificação de material herborizado por meio da observação de caracteres anatômicos), tendo a maior $14 \mathrm{~cm}$ de comprimento e $3,8 \mathrm{~cm}$ de largura, do exemplar n. 23.980 do herbário do Jardim Botânico (RB), que foi identificado por A.J.G.H. Kostermans (idenifificação confirmada por Ida de Vattimo) e coletado por A. Ducke no Estado do Amazonas.

A técnica de trabalho empregada foi a mesma descrita no trabalho sobre Aniba burchellii Kostermans (Vattimo, 1969).

\section{I — TECIDO EPIDÉRMICO SUPERIOR}

É constituído por células dispostas sem espaços entre si em um estrato e que podem ser incluídas em dois tipos de formas básicas, que caracterizam respectivamente duas áreas do tecido epidérmico e apresentam em geral as seguintes características:

No tipo que abrange a maior área, as células são heteromórficas e heterométricas e podem ser enquadradas em uma forma básica poliédrica irregular, de 6-12 faces, tendo um polígono irregular curvilíneo ou convexo, de tetragonal a hexagonal na face superior $e$ na inferior e 4-10 faces quadrilaterais. A membrana é fina, celulósica, nas faces laterais em geral é sinuosa; entretanto, algumas vezes, é curva, reta ou sub-reta, como acontece em geral nas faces superior e inferior.

No outro tipo, que ocorre sobre o sistema vascular, dispostas em fileiras irregulares, as células são heteromórficas e heterométricas e podem ser enquadradas em uma forma básica poliédrica convexa a hexaédrica, podendo ser a paralelepipedal, de faces paralelogrâmicas (a mais comum) ou a cúbica de fa-

(") - Jardim Botânico do Rio de Janeiro. Bolsista do CNPq. 
ces quadráticas. A membrana é fina, reta ou sub-reta em qualquer das faces. Às vezes as células podem apresentar alterações na forma, devido principalmente à influência da posição sobre a nervura. Em visão do plano frontal possuem as formas quadrangular ou subquadrangular e retangular ou subretangular, sendo estas duas últimas as mais comuns, medindo de comprimento de $12-45 \mu$ e de largura de $6-8 \mu$.

A cutina deposita-se em camadas sobre as faces superiores atingindo até $6 \mu$ de espessura total e até a metade das faces laterais das células (visão em corte transversal). Nesta segunda circunstância, é facilmente observável entre as células pela parte externa, dita cuticularizada.

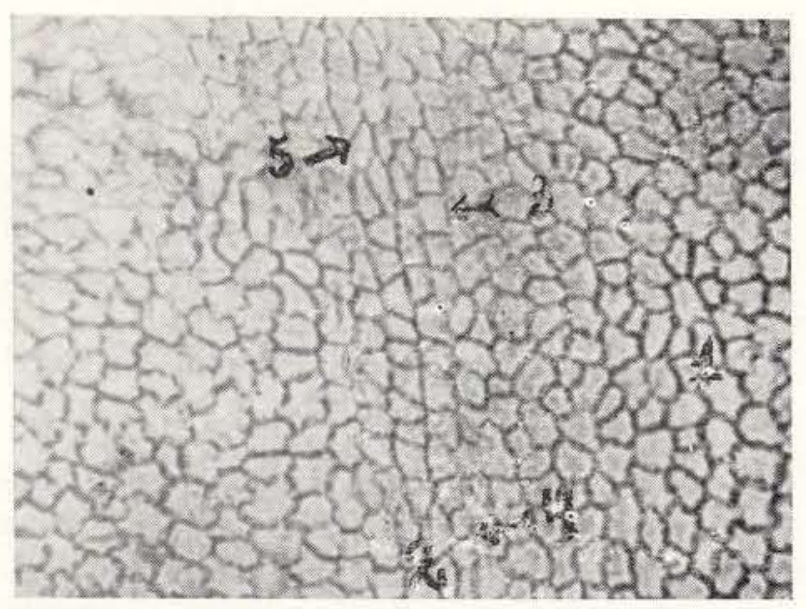

Fig. 1-Microfoto de Aniba permollis (Nees) Mez, epiderme superior, X 160,1) - Área das células com forma poliédrica irregular; 2) - Área das células com forma poliédrica, hexaédrica, paralelepipedal ou cúbica; 3 ) - Célula com a face superior de forma retangular; 4) - Célula com face superior de forma quadrangular; 5) - Célula com alteração da forma básica.

\section{II - TECIDO EPIDÉRMICO INFERIOR}

Constituído por células dispostas, sem espaços entre si, em um estrato e que podem ser incluídas em dois tipos de formas básicas, que caracterizam respectivamente duas áreas do tecido epidérmico e apresentam em geral as seguintes características:
No tipo que abrange a maior área, as células são papilosas, heteromórficas e heterométricas e podem ser enquadradas em uma forma básica poliédrica irregular. Possuem 6-12 faces, tendo um polígono irregular curvilíneo ou convexo, de tetragonal a decagonal na face superior papilosa e na face inferior e 4-10 faces quadrilaterais. A membrana é fina, nas faces laterais em geral é reta ou sub-reta ou, às vezes, curva ou sinuosa.

No outro tipo, sobre o sistema vascular, dispostas em fileiras irregulares, as células são heterométricas e heteromórficas e podem ser enquadradas em uma forma básica poliédrica convexa a hexaédrica, podendo ser a paralelepipedal de faces paralelogrâmicas (que é a mais comum) ou a cúbica de faces quadráticas. A membrana é fina e reta ou sub-reta em qualquer das faces. A face superior oode ser pap:losa, principalmente nas células das fileiras externas de ambos os lados, sobre as nervuras primárias ou secundárias, ou de qualquer fileira quando sobre as nervuras pseudo-secundárias, terciárias ou dos feixes vasculares restantes. Às vezes as células podem apresentar alterações na forma devido, principalmente, à influência da nervura e pelos. Em visão do plano frontal possuem as formas quadrangular ou subquadrangular e retangular ou subretangular, sendo estas duas as mais comuns, medindo de comprimento 12-60 $\mu$ e de largura 3-18 $\mu$ e dispondo-se com o comprimento no mesmo sentido do desenvolvimento em comprimento das nervuras.

A cutina deposita-se em camadas sobre as membranas superiores atingindo até $3 \mu$ de espessura total e na metade das membranas laterais das células (visão em corte transversal). Nesta segunda circunstância, é facilmente observável entre as células pela parte externa, dita cuticularizada. Observa-se ainda na epiderme inferior:

\section{PAPILAS}

As papilas possuem 3 partes: basal, média e o cume arredondado e podem ser enquadradas dentro de uma das formas básicas: circular ou elítica (visão do plano frontal), 
quando observada a membrana na parte do cume colocado o maior diâmetro da forma circular ou o eixo maior da forma elítica em plano focal. Quando adultas, podem apresentar formas irregulares. São semelhantes a vesículas não esclerosadas, cobertas por uma camada de cutina de até $3 \mu$ de espessura total, sendo as mais comuns as de dimensão média com a forma elítica.

As papilas podem apresentar diferentes posições: $1 .^{\circ}$ ) normal, perpendicular ao plano horizontal celular em que o eixo central imaginário que passa pelo centro da papila também passa pelo centro da célula, confirmandose isso com o fato de que a camada de cutina que existe sobre a papila aparece em espessura idêntica em toda a sua volta, quando observada a membrana na parte do cume, colocado o maior diâmetro da forma circular ou o. eixo maior da forma elítica em plano focal (visão do plano frontal); caso contrário, terá ocorrido inclinação da papila. Esta posição ocorre com as papilas das células da área entre os aparelhos estomáticos não sujeitas às influências dos mesmos, das nervuras ou espaços lisogênicos; $2 .^{\circ}$ ) ligeiramente inclinada, quando sujeita a pouca influência, o que ocorre com as papilas das células contíguas às que circundam os aparelhos estomáticos, próximas a espaços lisogênicos ou nervuras; 3. ) inclinada, sobre os aparelhos estomáticos cobrindo-os, possivelmente atraídas pela sua atividade.

\section{Mensurações das papilas em posição normal}

\section{Papilas jovens}

1. $\left.{ }^{\circ}\right)$ Forma circular com o diâmetro até $12 \mu ; 2^{\circ}{ }^{\circ}$ ) forma elítica com até $10,5 \mu$ de eixo. menor e até $12 \mu$ de eixo maior.

\section{Papilas médias}

1.0) Forma circular com o diâmetro acima de $12 \mu$ até $\left.21 \mu ; 2 .^{\circ}\right)$ forma elítica de $9 \mu$ até $20,5 \mu$ de eixo menor e de mais de $12 \mu$ até $21 \mu$ de eixo maior.

\section{Papilas adultas}

1.') Forma circular com o diâmetro acima de $21 \mu ; 2 .^{\circ}$ ) forma elítica de $12 \mu$ até $28,5 \mu$ de eixo menor e de mais de $21 \mu$ até $30 \mu$ de eixo maior.

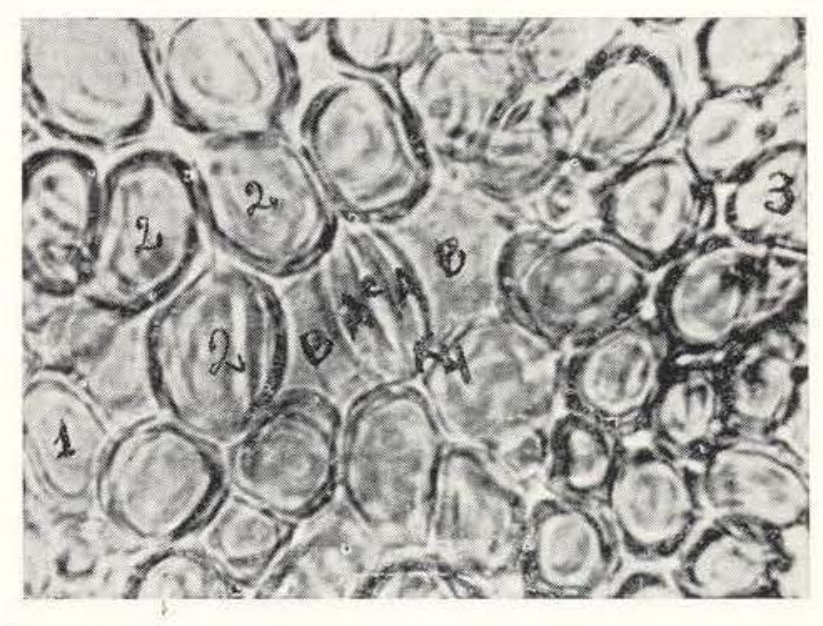

Fig. 2 - Microfoto de Aniba permollis (Nees) Mez, epiderme inferior, $\mathrm{X} 320$. 1) - Papila média; 2) - Papila adulta; 3) - Papila com parte do cume afinada; 4) - Aparelho estomático do tipo II na área das células epidérmicas papilosas de forma poliédrica irregular. A - células guardiãs; B células subsidiárias; C - ostíolo.

\section{APARखLHOS ESTOMÁTICOS (ESTÔMATOS)}

Os aparelhos estomáticos podem ser observados na epiderme inferior na área das células epidérmicas de forma poliédrica irregular ou na da polédrica, hexaédrica, paralelepipedal ou cúbica, apresentando em geral as seguintes características:

a) - Aparelhos estomáticos da área das células epidérmicas papilosas de forma poliédrica irregular.

Os aparelhos estomáticos quando exercem a sua atividade parecem influenciar diretamente as células subsidiárias, as que o contornam e algumas contíguas a elas, atraindo as papilas dessas células, ficando cobertos por 4-8 papilas. Quando cobertos por 7 ou 8 papilas, 5 ou 6 delas serão das células epidérmicas comuns que o circundam e 1 ou 2 das 
células subsidiárias, papilas estas que podem ou não ficar sob as outras.

São constituídos por duas células guardiãs plano-convexas (plana a face lateral interna e convexas as demais), superficiais quando o aparelho estomático está fechado e inclinadas quando está em atividade, com 21-30 $\mu$ de comprimento, 4,5-6 $\mu$ de maior largura e com até $3 \mu$ de eixo maior do ostíolo.

Possuem duas células subsidiárias paralelas ao eixo maior do aparelho estomático (tipo paracítico de Metcalf \& Chalk, 1950), heteromórficas e heterométricas. Enquadram-se em uma forma básica poliédrica irregular, com 6-10 faces, tendo um polígono irregular de tetragonal a octogonal na face superior, que pode ser ou não subpapilosa ou papilosa e outro polígono na inferior e 3-6 faces quadrilaterais, sendo a face contígua à célula guardiã de forma côncava e as demais planas. Às vezes possuem a forma poliédrica, hexaédri$\mathrm{ca}$, paralelepipedal, de face lateral interna côncava e as demais planas ou côncavas às faces laterais externa e interna e as demais planas.

O rompimento da cutina sobre o local do eixo menor do ostíolo parece ser devido ao fato de a turgescência das células guardiãs ocasionar uma força de expansão do conteúdo protoplasmático, que exerceria maior pressão sobre a parte central da face lateral-externa, que é a menos resistente, passando a célula à forma plano-convexa e determinando o acima citado rompimento da cutina.

Posteriormente com o transcorrer da atividade do aparelho estomático, o rompimento da cutina sobre o mesmo prossegue no sentido e em toda a extensão do eixo maior, estendendo-se depois, no sentido do eixo menor nos bordos da abertura, que vão se fragmentando em geral até a metade da largura das células guardiãs.

Este rompimento no sentido do eixo maior deve ocorrer devido à mudança das posições das células guardiãs que, quando fechadas, ficam superficiais e quando o aparelho estomático está em atividade, inclinam-se, o que o facilita. Esta posição inclinada das células guarciiãs além de parecer ser necessária para a abertura do aparelho estomático, parece obrigatória neste caso, por não haver possibilidade de maior expansão no sentido horizontal do plano celular quando estão túrgidas, ficando depresso o lado da face lateral-interna e que é também o do ostíolo e elevando-se o lado oposto, aparecendo então a cutina intercelular, entre as faces lateral-externa da célula guardiã e a côncava da célula subsidiária (placa de cutina sobre as células guardiãs observada em algumas espécies de Aniba Aubl. e designada "scale" por H. Bandulska (1926), e isto pode ser visto nos dois lados quando as células gua:diãs, ou a área em que estão, ficam em plano horizontal ou em um dos lados, quando ficam em plano oblíquo. Neste caso uma das células fica superficial e a outra depressa.

O lado que se eleva das células guardiãs pressiona a metade superior da face lateralinterna da célula subsidiária, tornando-a côncava e essa face permanece unida à face lateral-externa da célula guardiã.

b) - Aparelhos estomáticos da área das células ep dérmicas papilosas de forma poliédrica irregular ou da poliédrica hexaédrica, sobre as nervuras terciárias que formam retículos.

Com duas células guardiãs plano-convexas (plana a face lateral-interna e convexas as demais), superficiais quando o aparelho estomático está fechado e também superficiais ou ligeiramente inclinadas quando está em atividade, com 21-30 $\mu$ de comprimento, 4,5-6 $\mu$ de maior largura e com até $3 \mu$ de eixo menor do ostíolo.

Possuem duas células subsidiárias paralelas ao eixo maior do aparelho estomático (tipo paracítico de Metcalf \& Chalk, 1950), heteromórficas e heterométricas. Enquadram-se em uma forma básica poliédrica irregular, com 6-10 faces, tendo um polígono irregular na face superior não papilosa e 3-6 faces quadrilaterais, sendo a contígua à célula guardiã de forma côncava e as demais planas.

É possível que a turgescência das células guardiãs ocasione o rompimento da cutina so- 
bre o local do eixo menor do ostíolo, da mesma forma descrita para os estômatos do tipo I. As células guardiãs quando túrgidas se expandiriam pelo lado da sua face lateral-externa contígua à lateral-interna da célula subsidiária, tornando-a subcôncava, ficando nesta ocasião o aparelho estomático aberto e superficial. Entretanto, pelos motivos explicados na descrição dos estômatos do tipo I também podem se inclinar ligeiramente.

As papilas das células epidérmicas de qualquer das duas áreas, não conseguiriam cobrir esse tipo de aparelho estomático quando atraídas pela sua atividade, ao que parece devido ao grande desenvolvimento das células subsidiárias não papilosas. No entanto, pela disposição ao redor do mesmo e por se situarem, principalmente, na face da célula voltada para ele, proporcionariam resistência que mantém as faces lateral-interna da célula subsidiária e a externa da guardiã unidas e determinam o rompimento da cutina no sentido do eixo maior. O rompimento da cutina ocorre da mesma forma descrita nos estômatos do tipo I.

Estes estômatos aparecem em pouca quantidade na área das células epidérmicas de forma poliédrica irregular e suas células dispõem-se no mesmo sentido ou ao contrário ao das células epidérmicas comuns, quando na área sobre as nervuras terciárias. A largura do ostíolo é mais ou menos igual em todo o comprimento da abertura, devido às características já mencionadas nos estômatos do tipo I, exceto nas extremidades.

c) - Aparelhos estomáticos da área das células epidérmicas de forma poliédrica, hexaédrica, em geral sobre as nervuras primárias e secundárias.

Com duas células guardiãs plano-convexas (plana a face lateral interna e convexas as demais), superficiais quando o aparelho estomático está fechado e também superficiais ou ligeiramente inclinadas quando está em atividade (ver Caract. Gerais), com 21-30 $\mu$ de comprimento, 4,5-6 $\mu$ de maior largura e com até $3 \mu$ do eixo menor do ostíolo.
Possuem duas células subsidiárias paralelas ao eixo maior do aparelho estomático (tipo paracítico de Metcalf \& Chalk, 1950), heteromórficas e heterométricas. Enquadram-se em uma forma básica hexaédrica a paralelep:pedal de faces paralelogrâmicas, sendo a sua forma côncavo-plana (côncava a face lateral interna e planas as demais).

Os aparelhos estomáticos localizam-se em geral nas fileiras de células das margens e dispõem-se no mesmo sentido ou no contrário das células epidérmicas comuns. O rompimento da cutina ocorre na forma descr:ta nos ítens 2 e 3 do tipo I, exceto, que em geral isso só acontece no sentido do eixo maior. Tal fato parece ser devido à resistência que as células epidérmicas dessa área possuem em virtude da forma e disposição que apresentam como também à influência da nervura, não possibilitando a expansão das células guardiãs quando túrgidas no sentido horizontal do plano celular, obrigando-as a uma ligeira inclinação o que acaba ocasionando o rompimento da cutina no sentido mencionado.

A turgescência das células guardiãs parecc ocasionar o rompimento da cutina sobre o local do eixo menor do ostíolo da mesma forma descrita para os estomas do tipo I. As células subsidiárias não são papilosas e a largura do ostíolo é mais ou menos igual em todo o comprimento da abertura, devido às características já mencionadas nos estomas do tiro I, exceto nas extremidades.

PİLOS - como em Aniba burchellii Kostermans (Vattimo, 1969 e 1970).

\section{III - ESPAÇOS INTERCELULARES LISOGÊNICOS: como em Aniba burchellii Kostermans (lbid.).}

\section{SUMMARY}

The Author continues his study on the leaf anatomy of the Aniba Aubl. species known as rosewood, in order to organize a key for their identification, based upon leaf anatomic characters, in case of sterile herborized specimens. In the present 
paper upper and lower epidermises of the leaf of A. permollis (Nees) Mez are treated and, in resume, they may be characterized as follows:

I - Upper epidermic tissue - consists of two types of heteromorphic and heterometric cells, irregularly disposesd in one layer, without interceular spaces. The main type of cells has a 6-12 faced irregular polyhedrical basic form (being the upper and lower faces an irregular convex or curvilinear polygon) and 4-10 quadrilateral faces.

The other type of cells, that lay upon the vascular system, has a basic convex polyhedrical to hexahedrical basic form, that may be parallelepipedal with parallelogramic faces (the more common) or cubic with quadratic faces, with cellulosic recta or sub-recta, thin walls, having in paradermic view plane quadrangular or rectangular forms.

II -- Lower epidermic tissue - With the same types of cells described for the upper epidermis, but the main cell type has thin recta, sub-recta or sometimes curve or sinuous cellulosic walls, the external faces having papillae. Also occur in the lower epidermis:

1 - Papillary epidermic cells - the papillae present three parts: basal, median and round apex. They are like vesicles, not sclerotic and covered by a cutin layer. The positions and mensurations during their development are treated in this paper.

2 - Stomatic apparatus - appear in the lower epidermis and the types are treated in this paper.

3 - Hairs - unicellular, simple, deriving from transformation of simple epidermic cells. Their cytomorphology reveals three distinct parts: basal, median and sharp or obtuse apex.

III - Lysigenous spaces in the upper and lower epidermises - present the same characteristics as described for A. burchellii Kosterm. "(See Vattimo, 1970).

\section{Bibliografia Citada}

BANDULSKA, $\mathrm{H}$,

1926 - On the cuticles of some fossil and recent Lauraceae. J. Linn. Soc. Bot., 47: 383-425.

Kostermans, A. J. G. H.

1938 - Revision of the Lauraceae. V - A monograph of the genera Beilschmiedia and Aniba. Med. Bot. Mus. Herb. Rijks Univ., Utrecht 48: 866-928.

METCALF, C. R. \& ChalK, L.

1950 - Anatomy of the Dicotyledons, 2. Oxford University Press, p. 1147-1152.

VATtimo, Italo de

1969 - Citomorfologia da folha das espécies conhecidas de pau-rosa. V - Estudo do limbo de A. burchellii Kosterm. Atas Soc. Biol., Rio de Janeiro, 12(4): 181-184.

1970 - Anatomia da folha das espécies conhecidas de pau-rosa. VIII - Citomorfologia das epidermes superior e inferior de A. burchellii Kosterm. Rev. Bras. Biol., 30(3): 419-429. 